\title{
КРИМІНАЛЬНО-ПРАВОВІ ОЗНАКИ СЕПАРАТИЗМУ
}

\author{
СТИРАНКА Михайло Богданович - аспірант кафедри кримінально- \\ правових дисциплін Львівського державного університету внутрішніх справ
}

DOI 10.32782/NP.2020.4.28

Надається характеристика доктринальних підходів до категорії “сепаратизм” у контексті захисту територіальної иілісності та протидї сепаратизму в Україні. Стверджується, що на сучасному етапі розвитку держави бракує адекватного механізму протидіi сепаратизму.

Проаналізовано теоретичні та нормативні аспекти поняття сепаратизму, визначені підстави виникнення иього явища, надано класибікаиію видів сепаратизму за визначеними критеріями, а також видів та борм сепаратистських рухів як діяльності, спрямованої на реалізацію сепаратизму. Сепаратизм та його прояви можуть бути класибіковані за різними критеріями, шо дають змогу виділити їх види та борми. Правильна квалібікація сепаратистсъкого руху необхідна як для оцінки обгрунтованості вимог, що він пред'являе, так i вироблення стратегї для ефективного вирішення конблікту.

Ключові слова: сепаратизм, територіальна иілісність, кримінально-правова охорона, національна безпека, протидія, кримінальноправова відповідальність, злочин.

Постановка проблеми

Анексія АРК, самопроголошення так званих $\curlywedge$ нР та ДНР, численні напади на Маріуполь та інші аналогічні події в Україні, які мають місце з кінця 2013 року по сьогодні, диктують нагальність наукового осмислення поняття сепаратизму. У ЗМІ ці події називають по різному: від спроби реалізації права нації на самовизначення, націоналізму до сепаратизму, тероризму. Вочевидь, що таке різноголосся щодо оцінки (щоправда, неофіційної) пов'язані не лише із приналежністю тих чи інших осіб до відповідної сторони конфлікту, а також із відсутністю єдиного правового підходу.

Сепаратистські процеси підривають основи громадянського миру в державі, знижують іiї міжнародний престиж, ставлять під сумнів легітимність центральної влади, призводять до кризи загальнодержавної політики та, створюючи загрозу державному суверенітету, підривають територіальну цілісність держави, оскільки безпосередньо пов'язані з питанням зміни іï кордонів та утворенням нових держав. Окрім того, прояви сепаратизму сприяють росту злочинності в державі, зокрема екстремізму, тероризму, а також порушують політичні та соціальноекономічні права громадян. У КК України термін «сепаратизм» чи інші похідні від нього поняття не застосовуються. Водночас посилання на нього міститься у назві ЗУ «Про внесення зміни до Кримінального кодексу України щодо кримінальної відповідальності за фінансування сепаратизму» від 19 червня 2014року № 1533-VII, на підставі якого КК України було доповнено ст.110-2. Відповідні зміни породили численні дискусії щодо того, які суспільно небезпечні дії охоплюються поняттям «сепаратизм». За таких умов цілком очевидно, що пошук шляхів протидії сепаратизму кримінально-правовими засобами потребує визначення його обсягу, який визначається шляхом його поділу на види. 


\begin{abstract}
Аналіз останніх досліджень
Наукові розвідки в частині з'ясування поняття сепаратизму, його форм, причин та умов виникнення розпочаті у рамках галузей конституційного права, політології, соціології тощо. Зокрема, мова йде про праці таких вітчизняних науковців, як О. А. Агарков, К. М. Вітман, В. А. Горенкин, Н. В. Горло, В. В. Дівак, І.О.Кресіна, А.А.Коваленко, І. Й. Магновський, В. С. Наконечний, В. В. Рахмайлов, О. О. Резнікова, А.С. Сталенна,О.О. Цебенко, В. Я. Явір та інших. Цінність робіт цих авторів зумовлена тим, що в них аналізується сепаратизм в аспекті його типологічних характеристик, здійснюється аналіз ефективності застосування окремих методів і способів його протидії, осмислюються його філософські, конфліктологічні та політичні основи. Водночас доводиться констатувати, що зміст поняття сепаратизму у науковій літературі вивчений фрагментарно, оскільки типологія сепаратизму $є$ різноплановою, а відтак і різняться його ознаки.
\end{abstract}

\section{Постановка завдання}

Метою даної статті є визначення кримінально-правових ознак сепаратизму.

\section{Виклад основного матеріалу}

Насамперед слід зазначити, що спільними кримінально-правовими ознаками 6 ті, які характерні для будь-якого складу злочину про сепаратизм. Їх, зокрема, доцільно розглянути за усталеним у кримінальному праві алгоритмом аналізу ознак складу злочину.

Насамперед зауважимо, що сепаратизм посягає на територіальну цілісність і недоторканність (у разі відділення від держави окремих територій), а також територіальний устрій (у разі автономії окремих територіальних суб'єктів) держави, які є окремими елементами територіального суверенітету. Відтак «цілісність» трактується як стан внутрішньої єдності об’єкта, його відносна незалежність від навколишнього середовища, а «недоторканний» розглядається як такий, що охороняється від посягань 3 боку будького або такий, якого не можна знищувати через важливість [1, с. 758, с. 1587]. У теорії кримінального права нема одностайності 3 приводу співвідношення понять «територіальна цілісність» та «територіальна недоторканність». Одні автори фактично ототожнюють ці поняття, визначаючи територіальну недоторканність через поняття цілісність [2, c. 205; 3, с. 27], натомість інші їх таки вирізняють. Зокрема, за результатами анкетування, 67 \% опитаних вважають, що ці поняття є тотожними, $21 \%$ переконані у протилежному, ще $12 \%$ респондентів не змогли визначитися.

О. О. Гречко вважає, що цілісність означає внутрішню єдність, а недоторканність передбачає гарантованість від зовнішніх зазіхань [4, с. 13]. Схожий погляд має М. I. Рубащенко, який зауважує, що цілісність характеризує стан території України з позиції його просторових параметрів (єдність та неподільність), а недоторканність - стан того самого об'єкта з позиції зовнішніх умов, у яких виявляється справжня соціальна цінність цього об’єкта. Відтак учений пише, що посягання на цілісність території України є завжди посяганням на іiі недоторканність, однак не кожне посягання на недоторканність заподіює шкоду цілісності [5, с. 224225]. Погоджуючись із таким твердженням, зазначимо: попри те, що поняття «територіальна цілісність» та «недоторканність» взаємообумовлюють одне одного, втім не може йтися про їхню тотожність. Скажімо, у разі збільшення території України шляхом незаконного заволодіння частиною території іншої держави, територіальній цілісності шкоди дійсно не заподіюється, бо територія України не зменшилась. А от недоторканність іï порушена.

Наступною ознакою сепаратизму як родового кримінально-правового поняття є те, що він охоплює суспільно небезпечні посягання, які мають вияв у відповідних діях. Такий висновок випливає з аналізу особливостей конструкцій складів злочинів про сепаратизм, які фактично засвідчують неможливість вчинення аналізованих посягань у формі бездіяльності. Незалежно від способу посягання на територіальну цілісність та недоторканність, а також територіальний устрій держави (насильницький чи ненасильницькій) такі злочинні діяння вчи- 


\section{Дискусії, обговорення, актуально}

няються лише в активній формі (наприклад, участь у бойових діях, юридична фіксація зміни фізичних параметрів території.

Як ознаку сепаратизму належить вважати й те, що така злочинна діяльність здійснюється всупереч встановленому національними та міжнародними актами порядку. Її небезпека криється у тому, що сепаратизм негативно позначається на функціонуванні держави, порушуючи принципи іï геополітичної безпеки. Прояви сепаратизму дестабілізують ситуацію в державі, стають причиною збройних конфліктів та, врешті, призводять до загибелі людей. Показово, що за результатами анкетування 92 \% опитуваних стикалися з проявами сепаратизму.

Не випадково одним із пріоритетних завдань ООН є боротьба з цим злочинним явищем. Утім політолог В. Майданюк стверджує, що сепаратизм 6 насамперед національно обгрунтованою боротьбою за незалежність, у якій за волю бореться народ, що є відмінним від титульного етносу метрополіï. На його думку, не так давно справжніми сепаратистами були й українці, від козаків гетьмана Івана Мазепи до воїнів Української Народної Республіки та Української повстанської армії, які прагнули відокремити Україну від московської централізованої імперії [6]. Проте таку позицію не можна схвалити, оскільки, найімовірніше, йдеться не про сепаратизм, а про право народів на самовизначення, яке позиціонується як один із принципів міжнародного права. Зокрема, у Декларації про принципи міжнародного права, які стосуються дружніх відносин і співробітництва між державами, відповідно до Статуту ООН від 24 жовтня 1970 р., зазначено, що всі народи мають право вільно визначати свій політичний статус і здійснювати економічний, соціальний і культурний розвиток, і кожна держава повинна поважати це право. Формами здійснення народом права на самовизначення 6 створення суверенної і незалежної держави, вільне приєднання до незалежної держави або об'єднання з нею, або встановлення іншого політичного статусу, вільно визначеного народом.

Цьому принципу протистоїть принцип територіальної цілісності та непорушності кордонів для унеможливлення зовнішньої підтримки сепаратизму. Зокрема, у ст. 6 Декларації про надання незалежності колоніальним країнам і народам від 14 грудня 1960 р. визначено, що будь-яка спроба, спрямована на те, щоб частково або повністю зруйнувати національну єдність і територіальну цілісність держави, несумісна з цілями і принципами Статуту ООН. Схожі положення передбачені також у Статуті ООН і Статуті Міжнародного суду від 26 червня 1945 р., Меморандумі про підтримку миру та стабільності в Співдружності Незалежних Держав від 10 лютого 1995 р., Меморандумі про гарантії безпеки у зв'язку з приєднанням України до Договору про нерозповсюдження ядерної зброї, підписаному 5 грудня 1994 р. тощо.

3 цього приводу у науковій літературі вказується, що міжнародне співтовариство, визначаючи право народів і націй на самовизначення, досі не може дати однозначної відповіді, як саме це право має кореспондувати $з$ правом на територіальну цілісність держав, за якою загальновизнаною процедурою воно має реалізовуватися. Це відтак слугує міжнародно-правовою основою для сепаратистських рухів та вигідне їм, позаяк завдяки неоднозначній реакції світової спільноти на їхню діяльність вони можуть розраховувати на досягнення своїх політичних цілей [7, с. 244, с. 246]. Така позиція не позбавлена раціональності, оскільки «взаємопроникнення» зазначених принципів часто ускладнюе відмежування проявів сепаратизму від права народів на самовизначення. Скажімо, за результатами анкетування, на запитання: «Чи тотожні, на Ваш погляд, поняття «сепаратизм» та «право на самовизначення народів?» 6,5\% респондентів дали позитивну відповідь, 83, 5\% переконані у протилежному, ще $10 \%$ не змогли визначитись.

Тим часом ці поняття не можна ототожнювати. Сепаратизм виражає специфічні інтереси вузької групи населення (не є масовим рухом), метою якого є розділення території держави, руйнування ії політичної, економічної, культурно-національної єдності, і аж ніяк не створення умов для благополуччя народу. Водночас відбувається не- 
хтування інтересами інших націй та розвивається національна неприязнь. Тобто так звана «сепаратистська діяльність»не передбачена і не може регламентуватися нормами ні національного, ні міжнародного права. Крім того, ідеї сепаратизму належать зовсім не народові, а насаджуються ззовні. Про це, зокрема, свідчать соціологічні дослідження 2014 р., відповідно до яких абсолютна більшість населення нашої держави сприймає Україну як свою Батьківщину, унітарну та неподільну [8].

Що стосується самовизначення народів, то воно не повинно здійснюватись із сепаратистських позицій на шкоду територіальній цілісності і єдності суверенних держав. С. В. Сьомін слушно зауважує, що рішення щодо відокремлення має прийматися винятково на референдумі в умовах миру і демократії, які забезпечуються легітимною владою. Самовизначення повинно відбуватися виключно за умов абсолютного рівноправ’я всіх громадян, пріоритету прав людини без переваг для корінних (титульних) етносів, без будь-якої дискримінації населення іншого етносу [9, с. 148]. Тобто воно не може здійснюватись так би мовити у довільній формі, оскільки реалізація цього принципу можлива у разі дотримання чітких правових умов (процедури виходу зі складу держави) лише на конституційних засадах. А отже, можна зробити висновок, що право на самовизначення, на відміну від суспільно небезпечного сепаратизму, має бути зреалізоване відповідно до національного і міжнародного законодавства.

Наступною ознакою сепаратизму як родового кримінально-правового поняття є те, що такі злочинні дії вчиняються тільки 3 прямим умислом. Про це власне вказує аналіз об'єктивної сторони розглядуваних складів злочинів, законодавчий спосіб опису суспільно небезпечних діянь яких однозначно засвідчує можливість учинення таких посягань із умисною формою вини у виді прямого умислу. Це продемонстрували і результати анкетування, згідно з якими більшість опитаних вважає, що прояви сепаратизму вчиняються лише з прямим умислом $(93,5$ \%). 3 огляду на це, визначення змісту вини аналізованих складів злочинів здійснювати- мемо через розкриття змісту інтелектуального та вольового критеріїв.

Останньою ознакою сепаратизму є спрямованість умислу на відокремлення від держави або утворення автономії у складі держави. Такий висновок грунтується безпосередньо на етимології поняття «сепаратизм», яке розглядається як рух, спрямований на відокремлення від частини держави задля створення нового державного утворення або набуття автономії [10, с. 284]. На цьому також акцентовано у Законі України «Про протидію і запобігання сепаратизму та подолання наслідків сепаратистської діяльності на території України (десепаратизацію)» від 22 липня 2014 № 4300.

\section{Висновки}

Отже, сепаратизм як родове кримінально-правове поняття охоплює умисні суспільно небезпечні посягання на територіальну цілісність, недоторканність або територіальний устрій держави, які мають вияв у діях, учинених всупереч порядку, встановленому національними та міжнародними актами, та спрямованих на відокремлення від території певної держави або утворення автономії у складі держави.

\section{Аітература}

1. Великий тлумачний словник української мови (з дод. і допов.). / уклад. і голов. ред. В. Т. Бусел. Київ; Ірпінь : ВТФ «Перун», 2007. 1736 c.

2. Таций В. Я. Особо опасные государственные преступления (Глава I. Раздел I Особенной части). Уголовнъий кодекс Украинской ССР. Научно-практический комментарий / авт. коммент. Н. Ф. Антонов и др. Киев : Политиздат Украины, 1987.С. 204-222.

3. Коржанський М. Й. Кримінальне право і законодавство України. Частина Особлива : курс лекцій / за ред. М. Й. Коржанського. Київ : Атіка, 2001. 544 с.

4. Гречко О. О. Принцип єдності та цілісності державної території як гарантія унітарного характеру Української держави. Право і Безпека. 2014. № 4 (55). С. 12-15.

5. Рубащенко М. А. Співвідношення понять «територіальна цілісність» та «тери- 


\section{Дискусіі, обговорення, актуально}

торіальна недоторканність» у кримінальному праві України (ст.110 КК). Науковий вісник Ужгородсъкого наиіонального університету. Серія «Право». 2014. Вип. 26. С. 223-226.

6. Майданюк В. Чому «сепаратисти» вигідніші за колабораціоністів? Вголос. URL: https://vgolos.com.ua/articles/chomuseparatysty-vygidnishi-za-kolaboratsionistiv 201937.html?print

7. Литвиненко О. К. Поняття та класифікація сепаратистських рухів Гілея : науковий вісник : збірник наукових праць. Вип. 108. C. 243-247.

8. Пояснювальна записка до проекту Закону України «Про внесення змін до Кримінального кодексу України» (щодо кримінальної відповідальності за фінансування сепаратизму) від 6 травня 2014 р. / народні депутати України: I. С. Ауценко,A. А. Кожем'якін. URL: http://w 1.c1.rada.gov. ua/pls/zweb2/webproc4_1?pf3511=50842

9. Сьомін С. В. Сепаратизм як загроза національній безпеці України. Стратегічні пріоритети. 2014. № 3 (32). С. 143-149.

10. Велика сучасна енциклопедія : в 10 т. Т. 9. / уклад. А. С. Івченко. Харків : Клуб сімейного дозвілля, 2013. 351 с.

\section{SUMMARY}

It is given characteristic of doctrinal approaches to the category of separatism in the context of protecting the territorial integrity and countering separatism in Ukraine. Conclusions are drawn that on the modern stage of state development there is no adequate mechanism of separatism countering in Ukraine.

The article analyzes the theoretical and normative aspects of the concept of separatism and the reasons for generation of this phenomenon, presents a classification of the types of separatism in accordance with specifc criteria as well as the ty pesand forms of separatist movements that could be defined as some activities aimed atimplementing separatism. Separatism and its manifestations can be classifed according to various criteria that allow us to identify their types and forms. The proper qualificationof a separatist movement is required in order to assess the validity of separatists' claimsand to develop some strategies for the effective resolution of a conflict.

Key words: separatism,territorial integrity, legal protection, national security, countering, criminal and legal liability, crime. 